Chapman University

Chapman University Digital Commons

Pharmacy Faculty Articles and Research

School of Pharmacy

2011

\title{
Thiazolyl N-Benzyl-Substituted Acetamide Derivatives: Synthesis, Src Kinase Inhibitory and Anticancer Activities
}

\author{
Asal Fallah-Tafti \\ Tehran University of Medical Sciences \\ Alireza Foroumadi \\ Tehran University of Medical Sciences \\ Rakesh Tiwari \\ ChapmanUniversity, tiwari@chapman.edu \\ Amir Nasrolahi Shirazi \\ Chapman University, shirazi@chapman.edu \\ David G. Hangauer \\ Kinex Pharmaceuticals \\ See next page for additional authors
}

Follow this and additional works at: http://digitalcommons.chapman.edu/pharmacy_articles

Part of the Amino Acids, Peptides, and Proteins Commons, Medical Biochemistry Commons, Medicinal and Pharmaceutical Chemistry Commons, and the Oncology Commons

\section{Recommended Citation}

Fallah-Tafti, Asal, et al. "Thiazolyl N-benzyl-substituted acetamide derivatives: synthesis, Src kinase inhibitory and anticancer activities." European journal of medicinal chemistry 46.10 (2011): 4853-4858. doi: 10.1016/j.ejmech.2011.07.050

This Article is brought to you for free and open access by the School of Pharmacy at Chapman University Digital Commons. It has been accepted for inclusion in Pharmacy Faculty Articles and Research by an authorized administrator of Chapman University Digital Commons. For more information,

please contact laughtin@chapman.edu. 


\section{Thiazolyl N-Benzyl-Substituted Acetamide Derivatives: Synthesis, Src Kinase Inhibitory and Anticancer Activities}

\section{Comments}

NOTICE: this is the author's version of a work that was accepted for publication in European Journal of Medicinal Chemistry. Changes resulting from the publishing process, such as peer review, editing, corrections, structural formatting, and other quality control mechanisms may not be reflected in this document. Changes may have been made to this work since it was submitted for publication. A definitive version was subsequently published in European Journal of Medicinal Chemistry, volume 46. issue 10, in 2011. DOI: 10.1016/

j.ejmech.2011.07.050

The Creative Commons license below applies only to this version of the article.

\section{Creative Commons License}

\section{(c) (1) $\Theta \Theta$}

This work is licensed under a Creative Commons Attribution-Noncommercial-No Derivative Works 4.0 License.

\section{Copyright}

Elsevier

\section{Authors}

Asal Fallah-Tafti, Alireza Foroumadi, Rakesh Tiwari, Amir Nasrolahi Shirazi, David G. Hangauer, Yahao Bu, Tahmineh Akbarzadeh, Keykavous Parang, and Abbas Shafiee 


\section{Thiazolyl $\mathbf{N}$-Benzyl-Substituted Acetamide Derivatives: Synthesis, Src Kinase Inhibitory and Anticancer Activities}

Asal Fallah-Tafti, ${ }^{1}$ Alireza Foroumadi, ${ }^{1}$ Rakesh Tiwari, ${ }^{2}$ Amir Nasrolahi Shirazi, ${ }^{2}$ David G. Hangauer, ${ }^{3}$ Yahao $\mathrm{Bu},{ }^{3}$ Tahmineh Akbarzadeh, ${ }^{1}$ Keykavous Parang, ${ }^{2,{ }^{*}}$ Abbas Shafiee ${ }^{1, *}$

${ }^{1}$ Department of Medicinal Chemistry, Faculty of Pharmacy and Pharmaceutical Sciences Research Center, Tehran University of Medical Sciences, Tehran 14176, IRAN; ${ }^{2}$ Department of Biomedical and Pharmaceutical Sciences, College of Pharmacy, The University of Rhode Island, Kingston, RI, 02881, USA; ${ }^{3}$ Kinex Pharmaceuticals, Buffalo, NY, 14203, USA.

kparang@uri.edu

TITLE RUNNING HEAD. Synthesis and evaluation of $N$-Benzyl Substituted Acetamide Derivatives of 4(2-Morpholinoethoxy)phenyl)thiazole as Src kinase inhibitors and anticancer agents

\section{${ }^{*}$ Corresponding authors:}

A. Shafiee: Faculty of Pharmacy, Tehran University of Medical Sciences, Tehran, Iran Tel.: +98 21 66954708; Fax: +98 21 66461178; E-mail: ashafiee@ams.ac.ir

K. Parang: 41 Lower College Road, Department of Biomedical and Pharmaceutical Sciences, College of Pharmacy, University of Rhode Island, Kingston, Rhode Island, 02881, USA; Tel.: +1-401-874-4471; Fax: +1-401-874-5787; E-mail address:

kparang@uri.edu. 


\section{Abstract}

KX2-391 (KX-01/Kinex Pharmaceuticals), N-benzyl-2-(5-(4-(2-

morpholinoethoxy)phenyl)pyridin-2-yl)acetamide, is a highly selective Src substrate binding site inhibitor. To understand better the role of pyridine ring and $\mathrm{N}$ benzylsubstitution in KX2-391 and establish the structure-activity relationship, a number of $N$-benzyl substituted (2-morpholinoethoxy)phenyl)thiazol-4-yl)acetamide derivatives containing thiazole instead of pyridine were synthesized and evaluated for Src kinase inhibitory activities. The unsubstituted $\mathrm{N}$-benzyl derivative (8a) showed the inhibition of c-Src kinase with $\mathrm{Gl}_{50}$ values of $1.34 \mu \mathrm{M}$ and $2.30 \mu \mathrm{M}$ in NIH3T3/c-Src527F and SYF/cSrc527F cells, respectively. All the synthesized compounds were evaluated for inhibition of cell proliferation of human colon carcinoma (HT-29), breast carcinoma (BT-20), and leukemia (CCRF-CEM) cells. 4-Fluorobenzylthiazolyl derivative $\mathbf{8 b}$ exhibited $64-71 \%$ inhibition in the cell proliferation of BT-20 and CCR5 cells at concentration of $50 \mu \mathrm{M}$.

KEYWORDS: Anticancer; Cell Proliferation; KX-2; Inhibitor; Src Kinase; Thiazole. 


\section{Introduction}

Src is the prototype and most widely studied member of one of the largest family of non-receptor protein tyrosine kinases (PTKs), known as the Src family kinases (SFKs) [1], which are key regulators of cellular proliferation, survival, motility and invasiveness [2-4]. Src was first discovered in viral sarcoma and thus was pronounced as "sarc". Src offers a promising molecular target for anticancer therapy, as increased Src activity upregulates a number of signaling cascades associated with tumor development and progression leading to increased cell growth, migration and invasion. Moreover, Src has been shown to play a critical role in other pathologic disorders, such as myocardial infarction [5], stroke [6], osteoporosis [7], and neurodegeneration [1].

In the last two decades, synthesis of Src kinase inhibitors has been based on designing ATP binding site inhibitors and substrate binding site inhibitors. Despite of the large variety in PTKs structural organization, their ATP binding site is mostly conserved. The ATP binding site competitive inhibitors of Src that mimic the binding of ATP are potent, but often lack selectivity in a panel of isolated kinase assays [8-10]. In contrary, the substrate binding site sequences of PTKs are less conserved, which results in improved selectivity and less toxicity of designed substrate binding site inhibitors when compared with those of ATP mimics targeting ATP binding site.

KX2-391 (KX-01/Kinex Pharmaceuticals) (Fig. 1) is a novel class and highly selective non-ATP Src kinase inhibitor that targets the substrate binding site of Src, has tubulin polymerization inhibition as a second mechanism of action, and is currently in Phase-2 testing for solid tumors [11]. KX2-391 was found to inhibit certain leukemia 
cells that are resistant to current commercially available drugs, such as those derived from chronic leukemia cells with the T3151 mutation. In pre-clinical animal models of cancer, orally administered KX2-391 was shown to inhibit primary tumor growth and to suppress metastasis. In combination with certain chemotherapeutic agents, KX2-391 was synergistic, thereby, offering the potential to prescribe lower doses of some current cytotoxic agents that have undesirable side effects.

\section{Please insert Figure 1 here.}

In addition, previous structural studies [12-14] have proven that occurrence of heterocyclic scaffolds such as thiazole may result in generating effective kinase inhibitors, including potent Src kinase inhibitors. Dasatinib (Fig. 1) with amino-thiazole moiety, is one of the potent pan-Src kinase inhibitors, which has been approved by FDA for the treatment of Gleevec-resistant CML $[15,16]$.

Since the crystal structure of substrate binding site with Src inhibitors is not available yet, the designing strategy for discovering selective Src substrate binding site inhibitors has been mostly based on screening rather than rational designing [17]. Considering these facts, and in continuation of our efforts to design small molecules as Src kinase inhibitor or anticancer agents [18], we herein report the synthesis a series of substrate binding site inhibitors by substituting pyridine ring in KX2-391 molecule with a thiazole group and introducing substitutions on the benzyl ring. Src kinase inhibitory and anticancer activities of the compounds were evaluated in cell-based assays. 


\section{Results and discussions}

\subsection{Chemistry}

Scheme 1 outlines the procedure for the synthesis of thiazolyl benzyl acetamides 8a-e. Commercially available 4-(2-chloroethyl)morpholine hydrochloride (1) was reacted with 4-hydroxybenzonitrile (2) in presence of $\mathrm{K}_{2} \mathrm{CO}_{3}$ in refluxing DMF for $24 \mathrm{~h}$ to yield 4-(2-morpholinoethoxy)benzonitrile (3). Subsequent reaction of 3 with ammonium sulfide at room temperature afforded 4-(2-morpholinoethoxy)benzothioamide 4. Treatment of $\mathbf{4}$ with ethyl 4-chloroacetoacetate resulted in the formation of thiazolyl derivative $\mathbf{5}$, which underwent basic ester hydrolysis to generate acetic acid derivative 6. Finally, the reaction of $\mathbf{6}$ with the corresponding benzylamines $7 \mathrm{a}-\mathbf{e}$ in the presence of 1-hydroxybenzotriazole (HOBt) and 1-(3-dimethylaminopropyl)-3-ethylcarbodiimide hydrochloride (EDCl) in acetonitrile afforded desired thiazolyl benzyl acetamides 8a-e.

Please insert Scheme 1 here.

\subsection{Biological Activity}

\subsubsection{Src Kinase Inhibitory Activity}

The compounds were evaluated in engineered Src driven cell growth assays in $\mathrm{NIH} 3 \mathrm{T3} / \mathrm{c}-\mathrm{Src527F}$ and SYF/c-Src527F cells. NIH3T3/c-Src527F cell line has 
constitutively active human Src driving growth. SYF/c-Src527F has Src, Yes, and Fyn mouse knockouts with cSrc527F added back. The results of Src kinase inhibitory activity of compounds $\mathbf{8 a - e}$ are shown in Table 1 and Fig. 2. Compound $8 \mathbf{a}$ with no substitution on $\mathrm{N}$-benzyl group showed $\mathrm{Gl}_{50}$ values of $1.34 \mu \mathrm{M}$ and $2.30 \mu \mathrm{M}$ in $\mathrm{NIH} 3 \mathrm{T3} / \mathrm{c}-\mathrm{Src527F}$ and SYF/c-Src527F cells, respectively, and was found to be the most potent compound of this series. Introducing of a fluoro group at position 4 of benzyl group led to a slight decrease of inhibitory activity in compound $8 \mathbf{b}\left(\mathrm{Gl}_{50}=\right.$ $1.49-2.51 \mu \mathrm{M}$ ) versus $8 \mathrm{a}$. Introducing of a methyl group at position 4 of benzyl group in $\mathbf{8 e}$ led to almost 4 -fold decrease of potency in comparison with $\mathbf{8 a}$. Similarly 2 chlorobenzyl and 3,4-dichlorobenzyl substituted analogs (8c and $\mathbf{8 d}$ ) showed significantly less inhibitory activities when compared to other compounds $\left(\mathrm{GI}_{50}\right.$ $=7.93-13.02 \mu \mathrm{M})$. The data suggest that incorporation of bulky groups, such as chlorine and methyl in compounds 8c-e with higher lipophilicity (Log P), results in decreased potency.

All the tested compounds were significantly less potent than KX2-391, suggesting that introducing thiazole replacement of pyridine has led to decreased activity. In other words, pyridine is possibly a pharmacophore of KX2-391 that has major interactions with Src substrate binding site. Nevertheless, none of the compounds were active in vitro assay against Src Kinase, which confirm earlier results that the peptide binding site is not well formed outside of cells and these compounds indeed inhibit Src in cellular environment when the substrate binding site is deeper for binding interactions.

\section{Please insert Table 1 here.}


Please insert Figure 2 here.

\subsubsection{Anticancer Activities}

The effect of the inhibitors at the concentration of $50 \mu \mathrm{M}$ on the cell proliferation of human colon adenocarcinoma (HT-29) cancer cells that overexpress c-Src [19], breast carcinoma (BT-20), and leukemia (CCRF-CEM) cells was also evaluated (Fig. 3). In general, compounds $8 \mathbf{a}$ and $8 \mathrm{c}$ showed moderate activity against CCR5 and BT-20 compared to doxorubicin (DOX) by inhibiting the cell proliferation by $30-40 \%$. On the other hand, compounds $\mathbf{8 b}, \mathbf{8} \mathbf{d}$, and $\mathbf{8 e}$ inhibited the cell proliferation of CCR5 and BT20 by $61-71 \%$, and HT-29 by $54-56 \%$ (Fig. 3).

Structure-activity relationship studies suggest that the presence of substituents at position 4 of benzyl ring (4-fluoro-, 3,4-dicholor, or 4-methyl) is critical for maximum anticancer activity as seen in compounds $\mathbf{8 b}, \mathbf{8 c}$, or $\mathbf{8 e}$. Compound $\mathbf{8 b}$ that showed high Src inhibitory potency against Src was consistently also active against all cancer cells. On the other hand, poor correlation was observed between Src kinase inhibitory potency and the inhibition of cell proliferation in cancer cells for other compounds. For example, while compound $\mathbf{8 a}$ that was one of the most potent Src kinase inhibitors in this class, showed much weaker anticancer activities versus other compounds. Thus, some other mechanisms may be involved rather than Src kinase inhibition in generating anticancer activity. 
Compounds $\mathbf{8 b}-\mathbf{e}$ have slightly higher lipophilicity than $\mathbf{8 a}$ as shown in Log $\mathrm{P}$ values. As can be seen in Fig. 3, after $72 \mathrm{~h}$ compounds $\mathbf{8 b}-\mathbf{e}$ exhibited significantly higher cell proliferation inhibitory activity when compared to that of $24 \mathrm{~h}$ in colon cancer cells HT-29. These data suggest that other factors like lipid solubility and cellular uptake may also contribute in anticancer activities of these compounds.

\section{Please insert Figure 3 here.}

\section{Conclusions}

In summary, a number of $N$-benzyl substituted (2-morpholinoethoxy)phenyl)thiazol4-yl)acetamide were prepared and evaluated for Src kinase inhibitory and anti cancer activities. Although the biological results revealed that introducing thiazole replacement of pyridine in KX2-391 led to decreased activity, the compounds retained Src kinase inhibitory activities at low micomolar range (1.34-13.02 $\mu \mathrm{M})$ in NIH3T3/c-Src527F and SYF/c-Src527F cells. Structure-activity relationship studies revealed that the presence of a substituent at position 4 of benzyl ring (4-fluoro-, 3,4-dicholor, or 4-methyl) is critical for maximum anticancer activity. For example, 4-fluorosubstituted (8b) and 3,4dichlorosubsitited (8d) analogs inhibited the cell proliferation of CCR5 by $71 \%$ and $69 \%$, respectively (Fig. 3). This study provides insights and structure-activity relationships for further optimization of this scaffold for generating optimal Src inhibitory and anticancer activities. 


\section{Experimental protocols}

\subsection{Materials and methods}

All starting materials, reagents, and solvents were purchased from Merck AG (Germany). The purity of the synthesized compounds was confirmed by thin layer chromatography (TLC) using various solvents of different polarities. Merck silica gel 60 F254 plates were applied for analytical TLC. Column chromatography was performed on Merck silica gel (70-230 mesh) for purification of the intermediate and final compounds. Melting points were determined on a Kofler hot stage apparatus (Vienna, Austria) and are uncorrected. ${ }^{1} \mathrm{H}$ NMR spectra were recorded using a Bruker $500 \mathrm{MHz}$ spectrometer (Bruker, Rheinstatten, Germany), and chemical shifts are expressed as $\delta$ (ppm) with tetramethylsilane (TMS) as an internal standard. Proton coupling patterns are described as singlet (s), doublet (d), triplet (t), quartet (q), multiplet (m), and broad (br). The IR spectra were obtained on a Shimadzu 470 (Shimadzu, Tokyo, Japan) spectrophotometer (potassium bromide disks). The mass spectra were run on a Finnigan TSQ-70 spectrometer (Finnigan, USA) at $70 \mathrm{eV}$. Elemental analyses were carried out on a CHN-O-rapid elemental analyzer (Heraeus $\mathrm{GmbH}$, Hanau, Germany) for $\mathrm{C}, \mathrm{H}$, and $\mathrm{N}$, and the results were within $\pm 0.4 \%$ of the theoretical values. 


\subsection{Chemistry}

5.2.1. 4-(2-Morpholinoethoxy)benzonitrile (3). A mixture of 4-(2chloroethyl)morpholine hydrochloride 1 (9.5 g, $0.05 \mathrm{~mol})$, 4-hydroxybenzonitrile 2 (6 g, $0.05 \mathrm{~mol})$ and $\mathrm{K}_{2} \mathrm{CO}_{3}(17.3 \mathrm{~g}, 0.13 \mathrm{~mol})$ in anhydrous DMF $(150 \mathrm{~mL})$ was refluxed for 24 h. After cooling the reaction mixture to room temperature, it was poured in to cold water $(100 \mathrm{~mL})$ with crushed ice $(100 \mathrm{~mL})$ and the resulted light brown precipitate was collected and dried to obtain pure 3 in $76 \%$ yield. IR $(\mathrm{KBr}): v=2217(\mathrm{CN}) .{ }^{1} \mathrm{H}$ $\operatorname{NMR}\left(\mathrm{CDCl}_{3}\right): \delta 7.59(\mathrm{~d}, J=9 \mathrm{~Hz}, 2 \mathrm{H},-\mathrm{ArH}), 6.96(\mathrm{~d}, J=9 \mathrm{~Hz}, 2 \mathrm{H},-\operatorname{ArH}), 4.16(\mathrm{t}, J=11.5$ $\left.\mathrm{Hz}, 2 \mathrm{H},-\mathrm{CH}_{2}\right), 3.74\left(\mathrm{t}, J=9 \mathrm{~Hz}, 4 \mathrm{H},-\mathrm{CH}_{2}\right), 2.83\left(\mathrm{t}, J=11.5 \mathrm{~Hz}, 2 \mathrm{H},-\mathrm{CH}_{2}\right), 2.58(\mathrm{t}, J=9$ $\mathrm{Hz}, 4 \mathrm{H},-\mathrm{CH}_{2}$ ). MS m/z (\%): $232[\mathrm{M}]^{+}$(45), 114 (12.5), 100 (100), 70 (25), 56 (48), 42 (36).

5.2.2. 4-(2-Morpholinoethoxy)benzothioamide (4). Ammonium sulfide ( $23 \mathrm{~mL}, 0.068$ mol) was added slowly to a stirring mixture of $3(8 \mathrm{~g}, 0.034 \mathrm{~mol})$ in DMF $(45 \mathrm{~mL})$ at room temperature. The mixture was stirred at the same temperature overnight and then was poured in to crushed ice $(150 \mathrm{~mL})$. The yellow precipitate was collected and dried to give pure 4 in $71 \%$ yield. IR $(\mathrm{KBr}): v=3370,3155\left(\mathrm{NH}_{2}\right), 1654(\mathrm{C}=\mathrm{S}) .{ }^{1} \mathrm{H} \mathrm{NMR}\left(\mathrm{CDCl}_{3}\right): \delta$ $7.90(\mathrm{~d}, J=9 \mathrm{~Hz}, 2 \mathrm{H},-\mathrm{ArH}), 7.58\left(\mathrm{br}, 1 \mathrm{H},-\mathrm{NH}_{2}\right), 7.16\left(\mathrm{br}, 1 \mathrm{H},-\mathrm{NH}_{2}\right), 6.91(\mathrm{~d}, J=9 \mathrm{~Hz}$, $2 \mathrm{H},-\mathrm{ArH}), 4.16\left(\mathrm{t}, J=11.5 \mathrm{~Hz}, 2 \mathrm{H},-\mathrm{CH}_{2}\right), 3.74\left(\mathrm{t}, J=9 \mathrm{~Hz}, 4 \mathrm{H},-\mathrm{CH}_{2}\right), 2.83(\mathrm{t}, J=11$ $\left.\mathrm{Hz}, 2 \mathrm{H},-\mathrm{CH}_{2}\right), 2.59\left(\mathrm{t}, \mathrm{J}=9 \mathrm{~Hz}, 4 \mathrm{H},-\mathrm{CH}_{2}\right) . \mathrm{MS} \mathrm{m} / \mathrm{z}(\%): 266[\mathrm{M}]^{+}$(88), 114 (12), 100 (100), 70 (16), 56 (32), $42(20)$. 
5.2.3. Ethyl 2-(2-(4-(2-morpholinoethoxy)phenyl)thiazol-4-yl)acetate (5). To a mixture of $4(6 \mathrm{~g}, 0.022 \mathrm{~mol})$ in ethanol $(60 \mathrm{~mL})$, ethyl 4-chloroacetoacetate $(3.5 \mathrm{~mL}$, $0.025 \mathrm{~mol}$ ) and a few drops of pyridine were added. The reaction mixture was then refluxed for $4 \mathrm{~h}$. After cooling to ambient temperature, the solvent was evaporated and the oily residue was purified by flash column chromatography $\left(\mathrm{CH}_{3} \mathrm{COOC}_{2} \mathrm{H}_{5} / n-\mathrm{C}_{6} \mathrm{H}_{14}\right)$ to give pure brownish oil of 5 in $54 \%$ yield. ${ }^{1} \mathrm{H} N M R\left(\mathrm{CDCl}_{3}\right): \delta 7.87(\mathrm{~d}, \mathrm{~J}=9 \mathrm{~Hz}, 2 \mathrm{H},-$ ArH), $7.46\left(\mathrm{~s}, 1 \mathrm{H},-\mathrm{CH}\right.$-thiazole), $7.11(\mathrm{~d}, \mathrm{~J}=9 \mathrm{~Hz}, 2 \mathrm{H},-\mathrm{ArH}), 4.11\left(\mathrm{~m}, 4 \mathrm{H},-\mathrm{CH}_{2}\right), 3.92$ (t, $\left.J=11 \mathrm{~Hz}, 4 \mathrm{H},-\mathrm{CH}_{2}\right), 3.85\left(\mathrm{~s}, 2 \mathrm{H},-\mathrm{CH}_{2}\right), 2.82\left(\mathrm{t}, J=11 \mathrm{~Hz}, 2 \mathrm{H},-\mathrm{CH}_{2}\right), 2.58(\mathrm{t}, J=9$ $\left.\mathrm{Hz}, 4 \mathrm{H},-\mathrm{CH}_{2}\right), 1.28$ (t, J=10 Hz, 3H, $-\mathrm{CH}_{3}$ ). MS m/z (\%): 376 [M] (8), 121 (100), 105 (72), 77 (36), 57 (24), 43 (28).

\subsubsection{2-(2-(4-(2-Morpholinoethoxy)phenyl)thiazol-4-yl)acetic acid (6). Sodium} hydroxide solution ( $30 \mathrm{~mL}, 1 \mathrm{~N})$ was added to a mixture of $5(4 \mathrm{~g}, 0.01 \mathrm{~mol})$ in ethanol $(20 \mathrm{~mL})$ and was refluxed overnight. The mixture was then cooled to ambient temperature and neutralized with $\mathrm{HCl}$. The remaining solvent was evaporated and the oily residue was purified by flash column chromatography $\left(\mathrm{CH}_{3} \mathrm{OH} / \mathrm{CH}_{3} \mathrm{COOC}_{2} \mathrm{H}_{5}\right)$ to give 6 in $42 \%$ yield. IR $(\mathrm{KBr}): v=3431(\mathrm{OH}), 1710(\mathrm{C}=\mathrm{O}) .{ }^{1} \mathrm{H}$ NMR $\left(\mathrm{DMSO}-\mathrm{d}_{6}\right): \delta$ $7.83(\mathrm{~d}, J=8.8 \mathrm{~Hz}, 2 \mathrm{H},-\mathrm{ArH}), 7.40(\mathrm{~s}, 1 \mathrm{H},-\mathrm{CH}$-thiazole), $7.04(\mathrm{~d}, J=8.8 \mathrm{~Hz}, 2 \mathrm{H},-\mathrm{ArH})$, 4.15 (t, $J=11.45 \mathrm{~Hz}, 4 \mathrm{H},-\mathrm{CH}_{2}$ ), $3.75\left(\mathrm{~s}, 2 \mathrm{H},-\mathrm{CH}_{2}\right), 3.58\left(\mathrm{t}, J=9 \mathrm{~Hz}, 4 \mathrm{H},-\mathrm{CH}_{2}\right), 2.71$ (t, $\left.J=11.45 \mathrm{~Hz}, 2 \mathrm{H},-\mathrm{CH}_{2}\right), 2.50$ (t, $\left.J=9 \mathrm{~Hz}, 4 \mathrm{H},-\mathrm{CH}_{2}\right) . \mathrm{MS} \mathrm{m} / \mathrm{z}(\%): 348[\mathrm{M}]^{+}(28), 114$ (64), 100 (100), 71 (20), 56 (28), 42 (16).

\subsubsection{N-Benzyl-2-(2-(4-(2-morpholinoethoxy)phenyl)thiazol-4-yl)acetamide (8a). A} mixture of acid $6(0.5 \mathrm{~g}, 1 \mathrm{mmol}), \mathrm{EDCl}(0.21 \mathrm{~g}, 1.1 \mathrm{mmol})$, and $\mathrm{HOBt}(0.15 \mathrm{~g}, 1 \mathrm{mmol})$ in dry $\mathrm{CH}_{3} \mathrm{CN}(10 \mathrm{~mL})$ was stirred at room temperature for 30 min and then treated with 
the benzyl amine $7 \mathrm{a}(0.11 \mathrm{~mL}, 1 \mathrm{mmol})$. The mixture was stirred at room temperature for an additional $24 \mathrm{~h}$. Then the solution was evaporated to dryness in vacuum. The residue was dissolved in ethyl acetate $(20 \mathrm{~mL})$ and washed sequentially with brine $(2 \times$ $5 \mathrm{~mL}), 10 \%$ aqueous sodium carbonate $(2 \times 5 \mathrm{~mL}), 10 \%$ aqueous citric acid $(2 \times 5 \mathrm{~mL})$, and water $(2 \times 5 \mathrm{~mL})$. The organic layer was dried over anhydrous sodium sulfate. Concentration of the dried extract yielded an oily residue, which was crystallized $\left(\mathrm{CH}_{2} \mathrm{Cl}_{2} / \mathrm{n}-\mathrm{C}_{6} \mathrm{H}_{14}\right)$ to give pure 8 a amide in $27 \%$ yield. M.P. $104-108{ }^{\circ} \mathrm{C} ;{ }^{1} \mathrm{H}$ NMR $\left(\mathrm{CDCl}_{3}\right): \delta 7.74(\mathrm{~d}, J=8.9 \mathrm{~Hz}, 2 \mathrm{H},-\mathrm{ArH}), 7.41(\mathrm{br}, 1 \mathrm{H},-\mathrm{NH}), 7.28(\mathrm{~m}, 5 \mathrm{H},-\mathrm{ArH}), 7.03(\mathrm{~s}$, $1 \mathrm{H},-\mathrm{CH}$-thiazole), $6.91(\mathrm{~d}, J=8.9 \mathrm{~Hz}, 2 \mathrm{H},-\mathrm{ArH}), 4.48\left(\mathrm{~d}, J=5.5 \mathrm{~Hz}, 2 \mathrm{H},-\mathrm{CH}_{2}\right), 4.24(\mathrm{~m}$, $\left.2 \mathrm{H},-\mathrm{CH}_{2}\right), 3.81\left(\mathrm{~m}, 4 \mathrm{H},-\mathrm{CH}_{2}\right), 3.78\left(\mathrm{~s}, 2 \mathrm{H},-\mathrm{CH}_{2}\right), 2.93\left(\mathrm{~m}, 2 \mathrm{H},-\mathrm{CH}_{2}\right), 2.71(\mathrm{~m}, 4 \mathrm{H},-$ $\left.\mathrm{CH}_{2}\right) ;{ }^{13} \mathrm{C} \mathrm{NMR}\left(\mathrm{CDCl}_{3}\right): \delta$ 39.09, 43.67, 53.93, 57.41, 65.58, 66.49, 114.88, 115.05, $126.42,127.32,127.54,127.92,128.64,138.17,150.40,160.19,168.52,169.04 ; M S$ $m / z(\%): 437[M]^{+}$(12), 114 (72) , 100 (100). Anal. calcd. for $\mathrm{C}_{24} \mathrm{H}_{27} \mathrm{~N}_{3} \mathrm{O}_{3} \mathrm{~S}: \mathrm{C}, 65.88 ; \mathrm{H}$, 6.22; N, 9.60; found: C, 65.46; H, 5.98; N, 9.79.

\subsubsection{N-(4-Fluorobenzyl)-2-(2-(4-(2-morpholinoethoxy)phenyl)thiazol-4-}

$y$ l)acetamide (8b). The same procedure described for $8 \mathbf{a}$ was used starting with 4fluorobenzylamine $7 \mathrm{~b}$, Yield $23 \%$. M.P. $148-151^{\circ} \mathrm{C} ;{ }^{1} \mathrm{H}$ NMR $\left(\mathrm{CDCl}_{3}\right): \delta 7.73(\mathrm{~d}, \mathrm{~J}=8.8$ $\mathrm{Hz}, 2 \mathrm{H},-\mathrm{ArH}), 7.42(\mathrm{br}, 1 \mathrm{H},-\mathrm{NH}), 7.23(\mathrm{~m}, 2 \mathrm{H},-\mathrm{ArH}), 7.02(\mathrm{~s}, 1 \mathrm{H},-\mathrm{CH}$-thiazole), 6.97(t, $J=17.4 \mathrm{~Hz}, 2 \mathrm{H},-\mathrm{ArH}), 6.91(\mathrm{~d}, J=8.8 \mathrm{~Hz}, 2 \mathrm{H},-\mathrm{ArH}), 4.43\left(\mathrm{~d}, J=5.5 \mathrm{~Hz}, 2 \mathrm{H},-\mathrm{CH}_{2}\right)$, $4.21\left(\mathrm{~m}, 2 \mathrm{H},-\mathrm{CH}_{2}\right), 3.77\left(\mathrm{~m}, 5 \mathrm{H},-\mathrm{CH}_{2}\right), 2.89\left(\mathrm{~m}, 2 \mathrm{H},-\mathrm{CH}_{2}\right), 2.66\left(\mathrm{~m}, 4 \mathrm{H},-\mathrm{CH}_{2}\right) ;{ }^{13} \mathrm{C}$ $\operatorname{NMR}\left(\mathrm{CDCl}_{3}\right): \delta 39.05,42.95,53.99,57.44,65.75,66.65,114.89,115.06,115.36$, $115.53,126.26,127.85,129.21,129.27,134.02,150.28,160.33,161.08,168.57$, 
169.04; MS m/z (\%): 455 [M] $]^{+}$(32), 114 (76), 100 (100). Anal. calcd. for $\mathrm{C}_{24} \mathrm{H}_{26} \mathrm{FN}_{3} \mathrm{O}_{3} \mathrm{~S}$ : C, 63.28; H, 5.75; N, 9.22; found: C, 63.87; H, 6.02; N, 9.53.

\subsubsection{N-(2-Chlorobenzyl)-2-(2-(4-(2-morpholinoethoxy)phenyl)thiazol-4-}

yl)acetamide (8c). The same procedure described for $8 a$ was used starting with 2chlorobenzylamine 7c, Yield 21\%. M.P. $114-116{ }^{\circ} \mathrm{C} ;{ }^{1} \mathrm{H}$ NMR $\left(\mathrm{CDCl}_{3}\right): \delta 7.81(\mathrm{~d}, \mathrm{~J}=9$ $\mathrm{Hz}, 2 \mathrm{H},-\mathrm{ArH}), 7.65(\mathrm{br}, 1 \mathrm{H},-\mathrm{NH}), 7.37(\mathrm{~m}, 1 \mathrm{H},-\mathrm{ArH}), 7.33(\mathrm{~m}, 1 \mathrm{H},-\operatorname{ArH}), 7.19(\mathrm{~m}, 2 \mathrm{H},-$ ArH), $7.00(\mathrm{~s}, 1 \mathrm{H},-\mathrm{CH}$-thiazole), $6.93(\mathrm{~d}, J=8.8 \mathrm{~Hz}, 2 \mathrm{H},-\mathrm{ArH}), 4.56(\mathrm{~d}, J=6 \mathrm{~Hz}, 2 \mathrm{H},-$ $\mathrm{CH}_{2}$ ), 4.17 (t, $\left.J=11 \mathrm{~Hz}, 2 \mathrm{H},-\mathrm{CH}_{2}\right), 3.75\left(\mathrm{~m}, 5 \mathrm{H},-\mathrm{CH}_{2}\right), 2.84\left(\mathrm{t}, J=10 \mathrm{~Hz}, 2 \mathrm{H},-\mathrm{CH}_{2}\right.$ ), $2.60\left(\mathrm{~m}, 4 \mathrm{H},-\mathrm{CH}_{2}\right) ;{ }^{13} \mathrm{C} \mathrm{NMR}\left(\mathrm{CDCl}_{3}\right): \delta 39.03,41.47,54.00,57.45,65.76,66.70$, $114.84,114.97,126.27,127.00,127.90,128.71,129.39,129.83,133.57,135.72$, 150.26, 160.31, 168.62, 169.03; MS m/z (\%): $473[\mathrm{M}+2]^{+}(8), 471[\mathrm{M}]^{+}(16), 114$ (76),100 (100). Anal. calcd. for $\mathrm{C}_{24} \mathrm{H}_{26} \mathrm{CIN}_{3} \mathrm{O}_{3} \mathrm{~S}$ : C, 61.07; $\mathrm{H}, 5.55 ; \mathrm{N}, 8.90$; found: C, $60.87 ; \mathrm{H}, 5.89 ; \mathrm{N}, 8.35$.

\subsubsection{N-(3,4-Dichlorobenzyl)-2-(2-(4-(2-morpholinoethoxy)phenyl)thiazol-4-}

yl)acetamide (8d). The same procedure described for 8 a was used starting with 3,4dichlorobenzylamine 7d, Yield 33\%. M.P. $129-131.5{ }^{\circ} \mathrm{C} ;{ }^{1} \mathrm{H}$ NMR $\left(\mathrm{CDCl}_{3}\right): \delta 7.76$ (d, $J=$ $8.8 \mathrm{~Hz}, 2 \mathrm{H},-\mathrm{ArH}), 7.52(\mathrm{br}, 1 \mathrm{H},-\mathrm{NH}), 7.34(\mathrm{~d}, J=2.6 \mathrm{~Hz}, 2 \mathrm{H},-\operatorname{ArH}), 7.33(\mathrm{~s}, 1 \mathrm{H},-\operatorname{ArH})$, $7.10(\mathrm{~d}, J=10 \mathrm{~Hz}, 1 \mathrm{H},-\mathrm{ArH}), 7.03(\mathrm{~s}, 1 \mathrm{H},-\mathrm{CH}$-thiazole), $7.94(\mathrm{~d}, J=8.8 \mathrm{~Hz}, 2 \mathrm{H},-\mathrm{ArH})$, $4.42\left(\mathrm{~d}, \mathrm{~J}=5.8 \mathrm{~Hz}, 2 \mathrm{H},-\mathrm{CH}_{2}\right), 4.18\left(\mathrm{~m}, 2 \mathrm{H},-\mathrm{CH}_{2}\right), 3.79\left(\mathrm{~s}, 2 \mathrm{H},-\mathrm{CH}_{2}\right), 3.75(\mathrm{~m}, 4 \mathrm{H},-$ $\left.\mathrm{CH}_{2}\right), 2.84\left(\mathrm{~m}, 2 \mathrm{H},-\mathrm{CH}_{2}\right), 2.60\left(\mathrm{~m}, 4 \mathrm{H},-\mathrm{CH}_{2}\right) ;{ }^{13} \mathrm{C} \mathrm{NMR}\left(\mathrm{CDCl}_{3}\right): \delta 39.01,42.46,53.92$, $57.39,65.62,66.47,114.98,115.19,126.30,126.88,127.89,129.32,130.54,131.25$, 132.62, 138.68, 150.11, 159.72, 160.30, 168.74, 169.20; MS m/z (\%): $507[\mathrm{M}+2]^{+}(8)$, 
$505[\mathrm{M}]^{+}$(12), 114 (76),100 (100). Anal. calcd. for $\mathrm{C}_{24} \mathrm{H}_{25} \mathrm{Cl}_{2} \mathrm{~N}_{3} \mathrm{O}_{3} \mathrm{~S}: \mathrm{C}, 61.43 ; \mathrm{H}, 5.68 ; \mathrm{N}$, 8.77; found: C, 61.98; H, 6.02; N, 8.14.

\subsubsection{N-(4-Methylbenzyl)-2-(2-(4-(2-morpholinoethoxy)phenyl)thiazol-4-}

yl)acetamide (8e). The same procedure described for $8 \mathbf{a}$ was used starting with 4methylbenzylamine 7e, Yield $18 \%$. M.P. $142-147{ }^{\circ} \mathrm{C} ;{ }^{1} \mathrm{H}$ NMR $\left(\mathrm{CDCl}_{3}\right): \delta 7.74(\mathrm{~d}, J=8.7$ $\mathrm{Hz}, 2 \mathrm{H},-\mathrm{ArH}), 7.35$ (br, 1H, -NH), 7.15 (d, J=7.9 Hz, 2H, -ArH), 7.09 (d, J=7.9 Hz, 2H, -ArH), 7.02(s, 1H, -CH-thiazole), 6.90 (d, J = 8.75 Hz, 2H, -ArH), $4.42(\mathrm{~d}, J=5.45 \mathrm{~Hz}$, 2H, $\left.-\mathrm{CH}_{2}\right), 4.17\left(\mathrm{t}, J=11.2 \mathrm{~Hz}, 2 \mathrm{H},-\mathrm{CH}_{2}\right), 3.77\left(\mathrm{~s}, 2 \mathrm{H},-\mathrm{CH}_{2}\right), 3.75$ (t, J=9.4 Hz, 4H, $\left.\mathrm{CH}_{2}\right), 2.85\left(\mathrm{t}, \mathrm{J}=11.2 \mathrm{~Hz}, 2 \mathrm{H},-\mathrm{CH}_{2}\right), 2.61\left(\mathrm{~m}, 4 \mathrm{H},-\mathrm{CH}_{2}\right), 2.32\left(\mathrm{~s}, 1 \mathrm{H},-\mathrm{CH}_{3}\right) ;{ }^{13} \mathrm{C} \mathrm{NMR}$ $\left(\mathrm{CDCl}_{3}\right): \delta$ 21.07, 39.08, 43.40, 54.01, 57.44, 65.81, 66.72, 114.83, 114.97, 126.31, $127.53,127.90,128.71,129.27,135.13,136.90,150.40,160.29,168.47,168.97 ; M S$ $m / z(\%): 451[\mathrm{M}]^{+}$(12), $114(60), 100$ (100). Anal. calcd. for $\mathrm{C}_{25} \mathrm{H}_{29} \mathrm{~N}_{3} \mathrm{O}_{3} \mathrm{~S}: \mathrm{C}, 66.49 ; \mathrm{H}$, 6.47 ; N, 9.31; found: C, $67.21 ; \mathrm{H}, 6.78 ; \mathrm{N}, 9.03$.

\subsection{Biological Assays}

\subsubsection{MTT Assay}

NIH3T3/c-Src527F (4500 cells per well) and SYF/c-Src527F (3500 cells per well) were seeded in cells in $100 \mu \mathrm{L}$ of DMEM media with $10 \%$ FBS in each well in a 96 -well plate and were incubated overnight at $37^{\circ} \mathrm{C}$ with $5 \% \mathrm{CO}_{2}$. Then, all the test compounds were diluted (5-point 2-fold serial dilution) in a separate 96 -well plate to yield $10 x$ of final 
concentrations. A volume of $10 \mu \mathrm{L}$ of $10 x$ dilutions was added to appropriate wells $(n=$ 3). $T_{0}$ value (reflecting the starting number of cells upon drug treatment) of 3 wells of cells was determined by following steps as described below.

SYF-C-Src527F cells were incubated for 2 days whereas NIH3T3/c-Src527F cells were incubated for 3 days at $37{ }^{\circ} \mathrm{C}$ with $5 \% \mathrm{CO}_{2}$. A volume of $10 \mu \mathrm{L}$ of MTT [20] solution ( $5 \mathrm{mg} / \mathrm{mL}$ in PBS) was added to each well and the mixture was incubated for 3 h at $37{ }^{\circ} \mathrm{C}$ with $5 \% \mathrm{CO}_{2}$. Then $100 \mu \mathrm{L}$ of $20 \%$ SDS with $0.01 \mathrm{M} \mathrm{HCl}$ were added to each well and the mixture was incubated overnight at $37^{\circ} \mathrm{C}$. Afterwards, $\mathrm{OD}_{570}$ was measured using microplate reader. The percentage of cell growth was calculated according to cell growth percentage $=\left(T-T_{0}\right) /\left(C-T_{0}\right) \times 100 \%$ or OD value of the test well exposure to test drug - OD value at time zero / (OD of the control well without drug treatment - OD value at time zero) $\times 100 \%$. Growth inhibition curves and $\mathrm{Gl}_{50}$ were determined using GraphPad Prism 5 software.

\subsubsection{Cell Culture and Cell Proliferation Assay}

5.3.2.1. Cell Culture. Human colon adenocarcinoma HT-29 (ATCC no. HTB-38), breast carcinoma cells BT-20 (ATCC no. HTB-19), leukemia CCRF-CEM (ATCC no. CCL-119) were obtained from American Type Culture Collection. Cells were grown on $75 \mathrm{~cm}^{2}$ cell culture flasks with RPMI-16 medium for leukemia and EMEM medium for colon adenocarcinoma and breast carcinoma and supplemented with $10 \%$ fetal bovine serum (FBS), and 1\% penicillin-streptomycin solution (10,000 units of penicillin and $10 \mathrm{mg}$ of streptomycin in $0.9 \% \mathrm{NaCl}$ ) in a humidified atmosphere of $5 \% \mathrm{CO}_{2}, 95 \%$ air at $37{ }^{\circ} \mathrm{C}$. 
5.3.2.2. Cell Proliferation Assay. Cell proliferation assay of compounds was evaluated in HT-29, CCRF-CEM, and BT-20 cells, and was compared with that of doxorubicin (DOX) according to the previously reported procedure [21]. Cell proliferation assay was carried out using CellTiter 96 aqueous one solution cell proliferation assay kit (Promega, USA). Briefly, upon reaching about $75-80 \%$ confluency, 5000 cells/well were plated in 96-well microplate in $100 \mu \mathrm{L}$ media. After seeding for $72 \mathrm{~h}$, the cells were treated with $50 \mu \mathrm{M}$ compound in triplicate. Doxorubicin (DOX, $10 \mu \mathrm{M}$ ) was used as the positive control. At the end of the sample exposure period (24-72 h), $20 \mu \mathrm{L}$ CellTiter 96 aqueous solution was added. The plate was returned to the incubator for $1 \mathrm{~h}$ in a humidified atmosphere at $37^{\circ} \mathrm{C}$. The absorbance of the formazan product was measured at 490 $\mathrm{nm}$ using microplate reader. The blank control was recorded by measuring the absorbance at $490 \mathrm{~nm}$ with wells containing medium mixed with CellTiter 96 aqueous solution but no cells. Results were expressed as the percentage of the control (without compound set at $100 \%$ ). The percentage of cell survival was calculated as OD value of cells treated with test compound - OD value of culture medium/(OD value of control cells - OD value of culture medium) $\times 100 \%$.

\section{Acknowledgments}

This work was supported by grants from the American Cancer Society Grant \# RSG-07-290-01-CDD, National Science Foundation, Grant Number CHE 0748555, and 
Research Council of Tehran University of Medical Sciences and Iran National Science Foundation (INSF).

\section{References}

[1] J.M. Summy, G.E. Gallick, Cancer Metastasis Rev. 22 (2003) 337-358.

[2] T.J. Yeatman, Nat. Rev. Cancer 4 (2004) 470-480.

[3] C.L. Yu, D.J. Meyer, G.S. Campbell, A.C. Larner, C. Carter-Su, J. Schwartz, R. Jove, Science 269 (1995) 81-83.

[4] G. Niu, K.L. Wright, M. Huang, L. Song, E. Haura, J. Turkson, S. Zhang, T. Wang, D. Sinibaidi, D. Coppola, R. Heller et al, Oncogene 21 (2002) 2000-2008.

[5] S. Weis, S. Shintani, A. Weber, R. Kirchmair, M. Wood, A. Cravens, H. McSharry, A. Iwakura, Y. Yoon, N. Himes, D. Burstein, J. Doukas, R. Soll, D. Losordo, D.A. Cheresh, J. Clin. Invest. 113 (2004) 885-894.

[6] R. Paul, Z.G. Zhang, B.P. Eliceiri, Q. Jiang, A.D. Boccia, R.L. Zhang, M. Chopp, D.A. Cheresh, Nat. Med. 7 (2001) 222-227.

[7] M. Susva, M. Missbach, J. Green, Trends Pharmacol. Sci. 21 (2000) 489-495.

[8] K. Parang, G. Sun, Expert Opin. Ther. Patents, 15 (2005) 1183-1207.

[9] S. Schenone, F. Manetti, M. Botta, Anticancer Agents Med. Chem. 7 (2007) $660-680$. 
[10] J.G. Trevino, J.M. Summy, G.E. Gallick, Mini. Rev. Med. Chem. 6 (2006) $681-687$.

[11] National Institutes of Health, Bethesda, MD, USA. (2007) http://www.clinicaltrials.gov/ct2/show/NCT00646139.

[12] L.J. Lombardo, F.Y. Lee, P. Chen, D. Norris, J.C. Barrish, K. Behnia, S. Castaneda, L.A.M. Cornelius, J. Das, A.M. Doweyko, C. Fairchild, J.T. Hunt, I. Inigo, K. Johnston, A. Kamath, D. Kan, H. Klei, P. Marathe, S. Pang, R. Peterson, S. Pitt, G.L. Schieven, Robert J. Schmidt, J. Tokarski, M.-L. Wen, J. Wityak, R.M. Borzilleri, J. Med. Chem. 47 (2004) 6658-6661.

[13] J. L.Buchanan, C.B. Vu, T.J. Merry, E.G. Corpuz, S.G. Pradeepan, U.N. Mani, M. Yang, H.R. Plake, V.M. Varkhedkar, B.A. Lynch, I.A. MacNeil, K.A. Loiacono, C.L. Tiong, D.A. Holt, Bioorg. Med. Chem. 9 (1999) 2359-2364.

[14] J.L. Buchanan, R.S. Bohacek, G.P. Luke, M. Hatada, X. Lu, D.C. Dalgamo, S.S. Narula, R. Yuan, D.A. Holt, Bioorg. Med. Chem. 9 (1999) 2353-2358.

[15] J. Das, P. Chen, D. Norris, R. Padmanabha, J. Lin, R.V. Moquin, Z. Shen, L.S. Cook, A.M. Doweyko, S. Pitt, S. Pang, D.R. Shen, Q. Fang, H.F.de Fex, K.W. Mclntyre, D.J. Shuster, K.M. Gillooly, K. Behnia, G.L. Schieven, J. Wityak, J.C. Barrish, J. Med. Chem. 49 (2006) 6819-6832.

[16] N.P. Shah, C. Tran, F.Y. Lee, P. Chen, D. Norris, C.L. Sawyers, Science, 305 (2004) 399-401.

[17] G. Ye, R. Tiwari, K. Parang, Curr. Opin. Investig. Drugs, 9 (2008) 605-613. 
[18] (a) A. Kumar, Y. Wang, X. Lin, G. Sun, K. Parang, ChemMedChem 2 (2007) 1346-1360; (b) A. Kumar, I. Ahmad, B. S. Chhikara, R. Tiwari, D. Mandal, K. Parang, Bioorg. Med. Chem. Lett. 21 (2011) 1342-1346; (c) D. Kumar, V. B. Reddy, A. Kumar, D. Mandal, R. Tiwari, K. Parang, Bioorg. Med. Chem. Lett. 21 (2011) 449-452; (d) D. Sharma, S. Bhatia, R. K. Sharma, R. Tiwari, C.E. Olsen, D. Mandal, J. Lehmann, K. Parang, V.S. Parmar, A.S. Prasad, Biochimie 92 (2010) 1164-1172; (e) R. Tiwari, A. Brown, S. Narramaneni, G. Sun, K. Parang, Biochimie 92 (2010) 1153-1163; (f) A. Kumar; G. Ye, Y. Wang, X. Lin, G. Sun, K. Parang, J. Med. Chem. 49 (2006) 3395-3401; (g) N.-H. Nam, G. Ye, G. Sun, K. Parang, J. Med. Chem. 47 (2004) 3131-3141; (h) B.H. Alizadeh, A. Foroumadi, S. Emami, M. Khoobi, F. Panah, S.K. Ardestani, A. Shafiee, Eur. J. Med. Chem. 45 (2010) 5979-5984; (i) A. Aliabadi, F. Shamsa, S.N. Ostad, S. Emami, A. Shafiee, J. Davoodi, A. Foroumadi, Eur. J. Med. Chem. 45 (2010) 5384-5389; (j) M. Mahmoodi, A. Aliabadi, S. Emami, M. Safavi, S. Rajabalian, M.A. Mohagheghi, A. Khoshzaban, A. Samzadeh-Kermani, N. Lamei, A. Shafiee, A. Foroumadi, Arch. Pharm. (Weinheim), 343 (2010) 411-416; (k) V.K. Rao, B.S. Chhikara, A.N. Shirazi, R. Tiwari, K. Parang, A. Kumar, Bioorg. Med. Chem. Lett. $21(2011) 3511-3514$.

[19] (a) A.P. Belches-Jablonski, J.S. Biscardi, D.R. Peavy, D.A. Tice, D.A. Romney, S.J. Parsons, Oncogene 20 (2001) 1465-1475; (b) R.J. Budde; S. Ke, V.A. Levin, Cancer Biochem. Biophys. 14 (1994) 171-175. 
[20] M.V. Berridge, P.M. Herst, A.S. Tan, Biotechnol. Ann. Rev. 11 (2005) 127-152.

[21] B.S. Chhikara, N. St Jean, D. Mandal, A. Kumar, K. Parang, Eur. J. Med. Chem. 46 (2011) 2037-2042. 